\title{
Historical Aspects of the Northern Canadian Treeline
}

\author{
HARVEY NICHOLS 1
}

\begin{abstract}
From palynological studies it appears that northernmost dwarf spruces of the tundra and parts of the forest-tundra boundary may be relicts from times of prior warmth, and if felled might not regenerate. This disequilibrium may help explain the partial incongruence of modern climatic limits with the present forest edge. Seedlings established as a result of recent warming should therefore be found within the northernmost woodlands rather than in the southern tundra.
\end{abstract}

RESUMÉ. Aspects historiques des limites forestières du Canada du nord. Il ressort des études palynologiques que les épinettes naines de la tundra et des régions limitrophes entre la tundra et les forêts peuvent être des reliquats de périodes de réchauffement antérieur et que si ces épinettes étaient abattues elles pourraient ne plus se régénérer.

Ce déséquilibre peut aider à expliquer le désaccord partiel entre les limites climatologiques de l'ère moderne et la lisière forestière actuelle. L'implantation de jeunes pousses sauvages due à un réchauffement récent devrait par conséquent se rencontrer dans les régions forestières les plus septentrionales plutôt que dans la tundra du sud.

\begin{abstract}
Ревюме. Историчесие аспекты северной араничы лесной зоны Канады. Палинологические исследования показывакот, что наиболее северные карликовые ели, растущие в тундре в районах границы с лесной воной, могут быть остаткамн растительности времен прежнего тёплого пернода и при вырубании могут вновь не произрастать. Это неравновесие может помочь объяснить частичное несоответствие между современными климатическими условиямн и гранидей леснои зоны. Благодаря недавнему потепленпо, новая поросль должна, таким обравом, появляться скорее в наиболее северной части лесной зоны, чем в южной части тундры.
\end{abstract}

\section{INTRODUCTION}

Evidence derived from plant macrofossils, and studies of the soil stratigraphy and palynology of a few widely-spaced locations has been used to establish the extent of northward movement of the Canadian Boreal forest-tundra ecotone during the postglacial (Bryson, Irving and Larsen 1965; Nichols 1967a, b, 1970, 1972; Ritchie and Hare, 1971 ; Sorensen et al. 1971). The current picture of the overall displacement of the forest-tundra ecotone during the maximum of Holocene summer warmth (hypsithermal) remains very fragmentary, due partly to logistical difficulties in the way of research in such areas. A suggested locus of the Arctic Front, which is thought to limit forest growth (Bryson 1966), has been mapped for certain episodes (Ritchie and Hare 1971); and a tentative scheme of the treeline variations since 6,000 B.P. along the $100^{\circ} \mathrm{W}$ meridian in the District of Keewatin produced (Nichols 1967b). In view of the slow progress of fieldwork in discovering

1Institute of Arctic and Alpine Research and Department of Environmental, Population and Organismic Biology, University of Colorado, Boulder, Colorado 80309, U.S.A. 
evidence for ecotonal movement, information from the available vegetation maps (Rowe 1959, 1972) is used in the present paper to help delimit hypsithermal range extension of the Boreal forest.

\section{THE MODERN ECOTONE}

Palynological and peat stratigraphic study of the Holocene fluctuations of this ecotone in response to climatic change (Nichols 1967a, b, 1970, 1972) has led inevitably to comparisons of the location of Canadian tree limit shown on the maps of Rowe $(1959,1972)$ with the present author's own field experience of some of these locations, especially in the area of Ennadai and Yathkyed lakes $\left(61-63^{\circ} \mathrm{N}\right.$, 98-101 ${ }^{\circ} \mathrm{W}$ ) in the District of Keewatin, Northwest Territories. The northernmost limit of trees (or tree-species) is often represented in Canada by dwarfed individuals of white spruce or black spruce (Picea glauca or P. mariana) in what appear to be clonal groups in sheltered locations such as river valleys or lake shores (see Larsen 1965, 1974; Savile 1972). These clones are spruces whose reproduction is primarily vegetative - by layering (Larsen 1974), which were derived originally from sexually-produced individuals. From Tauber pollen samplers, which were placed beside these diminutive spruces in the tundra of southern Keewatin as part of an aerobiological study (under the International Biological Program) of the carrying of Boreal forest pollen into the tundra, it has been shown that few of these spruces produced pollen in 1972 or 1973, a fact which is confirmed for the longer term (the last several decades) by pollen analysis of nearby samples of living moss and lichen (polsters). Cones were rarely seen on these diminutive Picea glauca trees, though the presence of a few specimens with cones shows that good seed years do occasionally occur in the tundra within 90 miles $(145 \mathrm{~km})$ of the modern forest limit (see Hustich 1966); however, seedlings were not seen at these locations. These observations are in agreement with comments made by Larsen $(1965,1974)$ on the vegetative reproduction of spruce in southern Keewatin; he reported that regeneration of felled trees in the north of the Ennadai Lake area had not occurred, and considered the spruce to be relicts of a more northerly distribution in the past. Hansell et al. (1971) have, however, recorded spruce seedlings near Aberdeen Lake, and suggest that spruce trees are re-establishing themselves, having moved northward during the last hundred years. They have contrasted the findings of Larsen (1965) on the relict status of the spruce clumps with the comments by Marr (1948) to the effect that the forest is migrating into the tundra as soil develops; this last point will be examined below.

\section{THE HISTORICAL TREELINE}

There are other data which may point to the historical or relict nature of present treeline in some areas. From "absolute" pollen analyses of topmost peat sections from the northeast shore of Great Bear Lake (near Port Radium) it has been shown that the present open spruce woodland there has been producing relatively small quantities of Picea pollen during the mostly cold summers of the last $\mathbf{7 0 0}$ radiocarbon years. The pollen productivity has been consistent with a more northerly location, which may suggest that the present forest limit there is at least in 
part due to historical climatic factors, namely previous warmer summer episodes (Nichols 1975).

The previous centuries appear from the palynological and peat stratigraphic records to have been dry and generally cold, with frequent incursions of dry cool air from the Arctic into these northern woodlands. The history of the northern woodland provides numerous instances of similar cold, dry climatic episodes having been followed by fires after which the trees did not become reestablished until the summer climate became warmer (Nichols 1975). The domination of the woodlands by increasingly frequent incursions of air from the Arctic in summer is thought to lead to desiccation, with increased likelihood of fire (Nichols 1967b). It would appear from this hypothesis that the present-day woodlands north of Great Bear Lake and elsewhere may be susceptible to eradication by fire and replacement by shrub tundra. The process is apparently an example of vegetational inertia in the face of environmental change due to the self-protective buffering effect of the local forest climate.

Fossil pollen diagrams have been prepared from sediments obtained from the environs of Coppermine, a coastal tundra location 140 miles $(225 \mathrm{~km})$ north of the Great Bear Lake sites. The sediments contained pieces of Picea wood throughout the lower peat from 3,715 \pm 120 B.P. (Geochron Laboratory no. GX-1813) to 2,500 B.P., but after that spruce wood was not found. Spruce macrofossils relating to a later period were not to be found. The very small quantities of spruce pollen in the sediments had been carried through the air over the long distances from woodlands in the south; from modern analogous pollen collections it is clear that the Coppermine spruces had not been releasing pollen. The foregoing evidence for the vegetative survival of relict spruces after forest retreat due to colder climate may be regarded as analogous to the suggested survival of the modern dwarf spruces in the tundra. The Coppermine spruces finally disappeared at a particularly cold episode due to increased climatic stress and/or to increased Eskimo use in relation to climatic deterioration (Nichols 1975 ).

The northernmost spruce outliers or "tree islands" may therefore be regarded as relicts of consistently warmer summers in the past, as Larsen (1965) and Savile (1972) also have suggested. Bryson (1966) and Barry (1967) have examined the degree of coincidence of the mean summer location of the Arctic Front with the forest-tundra boundary, and suggest that the cold dry arctic airmass inhibits the northward penetration of trees into the tundra, which implies that this summer position of the Front must previously have moved sufficiently far north to allow prolonged sexual reproduction of those dwarf spruces. From this hypothesis, it may be deduced that the mean summer position of the Arctic Front must have approached the present tree-species limit (see Fig. 1) at some time during the Holocene. Any spruce seeds which were blown farther north presumably would not consistently reproduce under the summer conditions of the arctic climate.

Two likely developments are suggested. The first involves brief climatic warming(s) when spruce seeds, transported north along waterways by flotation or wind dispersal over ice or snow crust, became established along rivers and lakes as isolated spruce colonies within the expanded Pacific airmass zone; and colder, drier summers followed the southward movement of arctic airmasses and pre- 


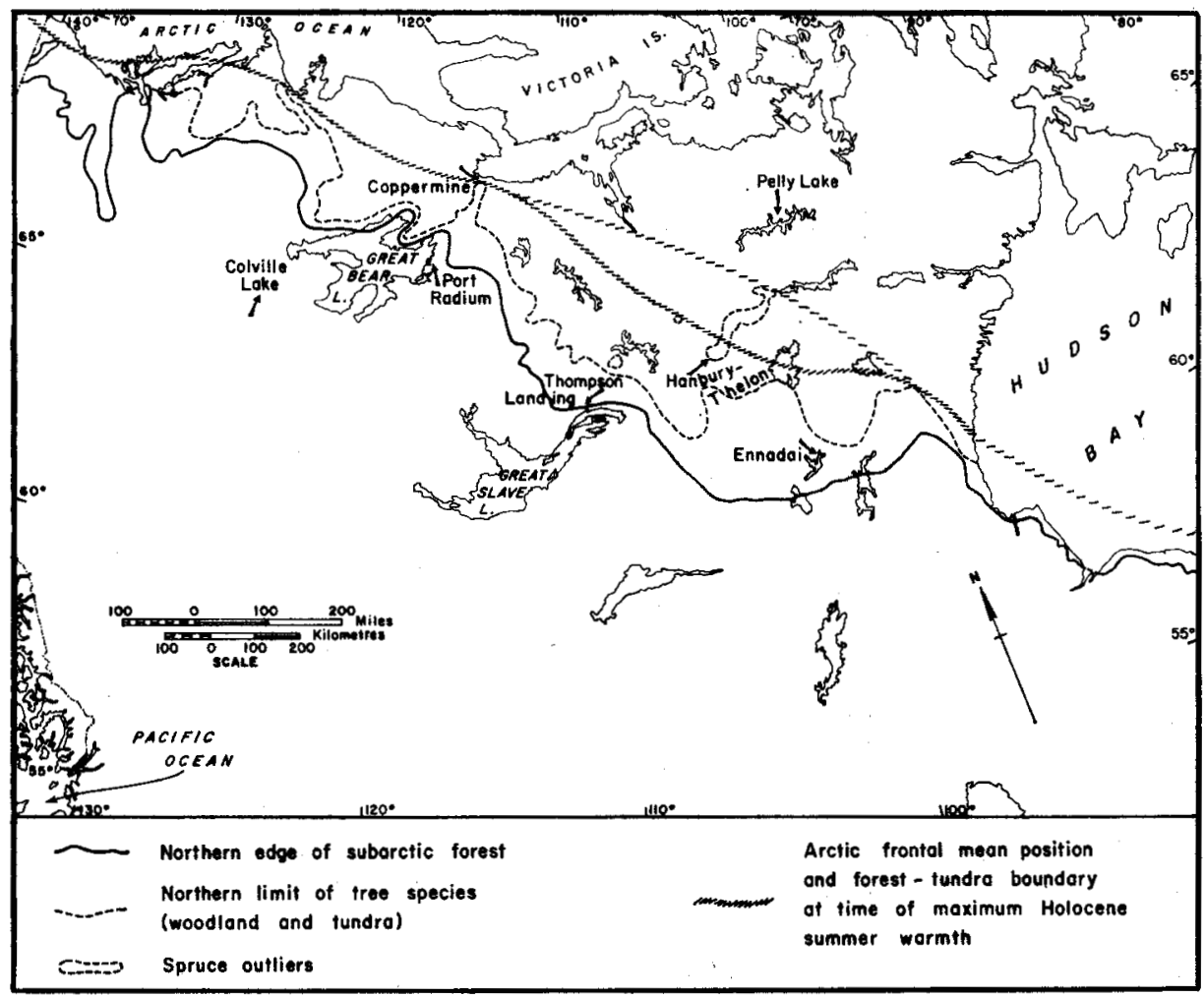

FIG. 1. Location map of central northern Canada. The hatched lines connect locations of apparently relict modern spruces which are thought to represent the former northernmost extension of spruce woodland. The most northerly hatched line is a more speculative position for the hypsithermal mean summer position of the Arctic Front. Vegetation boundaries are derived from Rowe (1972) and Larsen (1974).

vented expansion of these outliers. The second possibility is that, during prolonged periods of warmer summers, the forest ecotone moved north so as to include the modern "tree islands", and then retreated to leave the most protected, moist waterway sites occupied by spruce clones for up to several thousand years.

While the first explanation is the least demanding of environmental change, there is evidence that the second applies to a number of fossil forest sites not situated on waterways, where spruce wood and needles along with abundant preserved Picea pollen provide a record of the former existence of spruce forest in present-day tundra. Additional evidence for historical displacement of more or less continuous forest is the finding of: (a) continuous synchronous charcoal layers of spruce and larch lying up to 150 miles $(240 \mathrm{~km}$ ) north of present forest (Bryson, Irving and Larsen 1965), and (b) a series of five separate palynological sites on the tundra which provide a record of approximately synchronous (about 3,500 B.P.) forest fires over an east-west distance of almost a thousand miles $(1,600 \mathrm{~km})$ (Nichols 1967a, 1972, 1974, 1975).

It follows that even if, due to migrational lag, there was an insufficient interval 
of warming for the entire forest edge to move north so as to surround the spruce outliers, there was still a massive northward summer extension of the Boreal forest climatic zone, or "potential forest zone" - the zone of Pacific, modified arctic and indeterminate air, according to Bryson (1966).

From fossil palynological and soil studies in these areas of relict spruces, it is known that no northward forest displacement extending more than 100 miles $(160 \mathrm{~km})$ has occurred within the last 2,000 to 3,000 years (Nichols 1967a, 1972, 1975; Sorenson et al. 1971). The warming which occurred at about 1,200-1,000 B.P. allowed forest growth only about 70 miles $(110 \mathrm{~km})$ north of modern limits in southern Keewatin (Bryson, Irving and Larsen 1965). The last major northward displacement of the ecotone ended about 3,000 radiocarbon year ago at a series of palynological sites (Nichols 1975), so that the most northerly spruce clones may have survived since that time, or since 3,500 B.P. at least. The maxima of midHolocene summer warmth recorded in the course of palynological study in the central Canadian Subarctic appear to have occurred at about 5,200-4,800 B.P. and 4,000-3,800 B.P., so that the very northernmost clones may date from these episodes (Nichols 1975).

The suggested hypsithermal extension of Canadian treeline (Fig. 1) is derived from the northernmost tree-species limit (Rowe 1972) and locations where Larsen $(1965,1972)$ and the present author have examined dwarf spruces. From this extension, according to Bryson's (1966) hypothesis, a tentative reconstruction can be made of the mean summer hypsithermal position of the Arctic Front; and since the mean positions of major zones of the Front follow regular lines, the locus of the most northerly sites of tree species is a smooth curve. The question immediately arises: to what extent does the fitting of modern climatic parameters to the present treeline by Köppen (1936), Nordenskjøld and Mecking (1928), Hare (1950), Bryson (1966), Barry (1967), Krebs and Barry (1970) and others fail to bring about complete coincidence of the climatic and vegetational boundaries because of the historical nature of part of the northernmost treelines?

In a related matter, there is currently some uncertainty about the apparent lack of clear response of the Canadian Boreal forest-tundra ecotone to the instrumentally-recorded summer warming during the nineteenth and twentieth centuries. During extensive fieldwork in the region, Larsen $(1965,1972,1974)$ found that spruce seedlings did not grow consistently successfully in the southern reaches of the tundra. However, some seedlings associated with spruce clones have been found to grow much farther north (Hansell et al. 1971). The modern climatic warming may have been too small to move the "seedling treeline" northwards beyond the present woodland-tundra ecotone which was previously established under substantially warmer conditions. Thus, the hypothesis of the historicallyestablished position of some modern treelines implies that a consistently successful establishment of spruce seedlings due to that recent warming should also be searched for within the present northern woodlands, not just in the southern tundra.

This general hypothesis might also be applicable to the northern Eurasian treeline (see Krebs and Barry 1970), although the prehistoric and historic presence of man may have had an impact (Hustich 1966; Holtmeier 1973). It is possible to surmise that the failure of tree regeneration in the Rocky Mountains after histori- 
cally-dated fires is the result of some alpine treelines being in disequilibrium with modern climate, due to similar historical factors (Ives 1976).

The increase in mean summer temperature necessary for a consistently successful seedling growth up to 250 miles $(400 \mathrm{~km})$ north in the tundra can be extrapolated from modern ecotonal temperatures. It is one of $4^{\circ} \mathrm{C}$ or more $\left( \pm 1^{\circ} \mathrm{C}\right)$ in the present forest-tundra ecotonal areas of southeast District of Mackenzie and southwest District of Keewatin in the Northwest Territories. However, it should be noted that this estimate is based on short-term data from the only two relevant local meteorological stations at Ennadai Lake and Baker Lake.

It will be seen from Fig. 1 that the range of forest ecotonal fluctuation in the past appears to have been greater in central Keewatin than in the northwest of the District of Mackenzie, possibly by a factor of two. This suggestion seems to be supported by data from the historical field records: the range of forest movement in Keewatin since 3,700 B.P., has been at least 150 miles $(240 \mathrm{~km}$ ) (Bryson, Irving and Larsen 1965), whereas the north-south ecotonal movement indicated from a joint analysis of the Coppermine pollen diagrams and those from Port Radium on Great Bear Lake was limited to about 100 miles $(160 \mathrm{~km})$ for the equivalent period (Nichols 1975).

The numerous past fluctuations of the forest-tundra boundary are the probable reason for the existence of open tundra patches left isolated in the northern woodlands, the converse of the spruce relicts in the tundra. Such anomalies add to the naturally diffuse nature of an ecosystem boundary controlled by mean climatic values. Thus the north-south width of the present-day "forest and barren" communities mapped by Rowe (1972) - the area lying between the northern limit of tree species and the edge of the subarctic forest (Fig. 1) -- may give a rough measure of the late Holocene range of the ecotone. The compression of this transitional zone in the north-west is quite evident.

Higher ground north of treeline in the Canadian northwest is a possible explanation for the inhibition of northward forest expansion; for instance, between Great Bear Lake and Coppermine there is land above 1,000 feet $(300 \mathrm{~m})$, but it is not clear that this factor alone is responsible for the compression of the former treeline movements in northwest Canada, and one can deduce that the more level areas of the northwest have had relatively restricted ecotonal movements (Ritchie and Hare 1971). Two other factors are probably involved: the effect of the Arctic Ocean in depressing summer temperatures, and the "anchoring" effect of the northern cordillera on the upper atmospheric westerly waves (see Lamb 1966). Thus, while movements of the Arctic Front and the forest limit were quite restricted in the northwest, they were both freer to vary their positions in the continental interior.

\section{ALTERNATIVE INTERPRETATION}

There exists an interpretation of the past and present status of the forest-tundra ecotone from northeastern Canada which differs fundamentally from that set out in the foregoing discussion. Marr (1948) has interpreted data on current forest advance into the tundra on the east shore of Hudson Bay as being due to soil development and not to climatic effects. The result has been some uncertainty as 


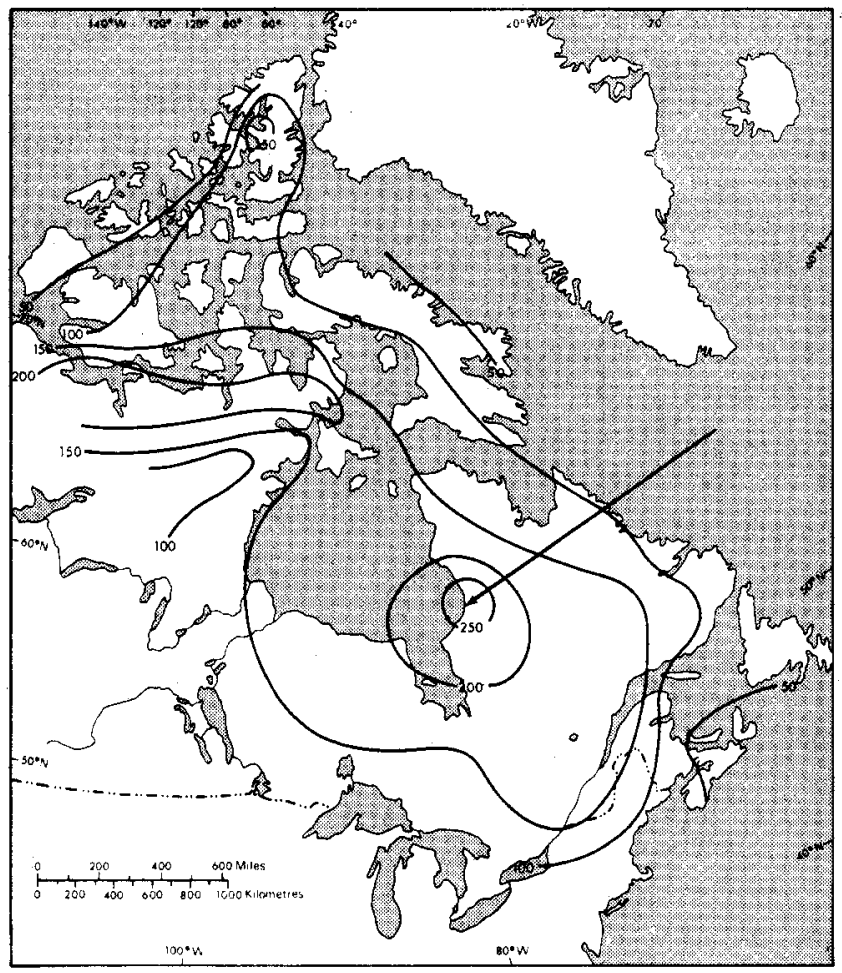

FIG. 2. The location of Marr's (1948) sites (arrow) in relation to isolines depicting Holocene isostatic uplift, measured in metres (reproduced from Andrews 1970).

to whether the northern forest edge has ever reached an equilibrium in Holocene climatic history, or has continued to respond to deglaciation of the landscape. This suggestion has not previously been challenged, as far as the present author is aware, but does require some evaluation.

The sites involved are at, or near, Great Whale River (approx. $55^{\circ} \mathrm{N}, 77^{\circ} \mathrm{W}$ ) and Richmond Gulf $\left(56^{\circ} \mathrm{N}, 77^{\circ} \mathrm{W}\right)$, both south of the northernmost limit of trees, and both on, or close to, the coast of Hudson Bay. These sites were chosen in what now appears to be an anomalous location for this type of study, for Hudson Bay was a centre of maximum ice load; and what is possibly the most rapid isostatic uplift in the world is still occurring at the sites - at least 1.5 metres per century according to Walcott (1972) and Andrews (1970). The total isostatic uplift there since 8,000 B.P. has been at least 900 feet $(275 \mathrm{~m})$ (Fig. 2). While recognition of isostatic effects was less normal at the time of his interpretation, Marr (1948 p. 119) did note the 800 feet $(244 \mathrm{~m})$ of shoreline displacement recognized by geological surveys.

At Cape Henrietta Maria $\left(55^{\circ} \mathrm{N}, 22^{\circ} 30^{\prime} \mathrm{W}\right), 220$ miles $(350 \mathrm{~km})$ distant across Hudson Bay, it has been shown that isostatic uplift of a similar magnitude has limited plant colonization of emerged land to the last several thousand years (Webber, Richardson and Andrews 1970). In the light of this, it seems likely that the spruce colonization recorded by Marr (1948) relates to this recent massive uplift and continuing emergence of land from the sea, with colonization guided by soil factors. Marr's implication that climate is not the factor which has limited the 


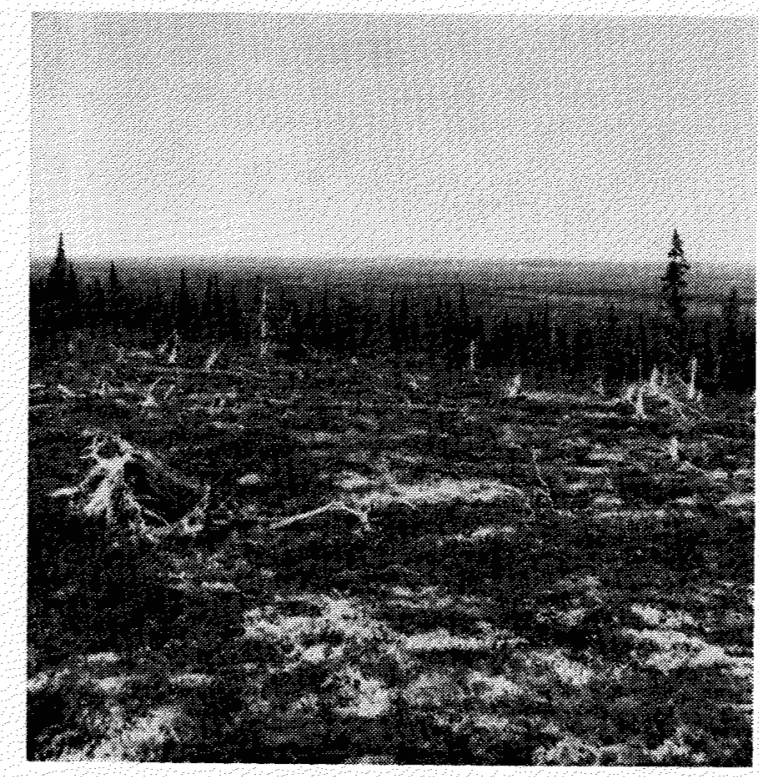

FIG. 3. Timber macro-fossil evidence of former tree growth in northern Labrador tundra. Photograph by J. D. Ives, 1958.

forest growth in northern Canada is thus unsubstantiated, although his thesis continues to influence scientific thought on the matter (Hansell et al. 1971 p. 233; Dunbar 1968 p. 97; Frenzel 1975 p. 105).

The likelihood that Marr's findings are of only local applicability is increased by the finding of massive sub-fossil spruce timbers eroding out of Holocene peat beds at sites in Labrador above modern treeline and in sites on the tundra-woodland margin where present-day trees are much smaller in diameter (Fig. 3). These sites were discovered in 1958 by J. D. Ives of the Institute of Arctic and Alpine Research, University of Colorado. The present author visited them with him in 1975; they suggest former tree growth under climates warmer than present-day and subsequent retraction of range due to cooling.

Similar implications may be drawn from six unpublished fossil pollen diagrams (which have radiocarbon-dating control) from the northern woodlands of Labrador, which show that the time of northward spruce expansion due to hypsithermal warmth has passed (Short 1976). The likelihood that the climaticallyinduced forest movements west of Hudson Bay (Nichols 1975) will be echoed in Labrador is enhanced by the palaeoclimatic correlation between northern Quebec and Keewatin (Bartley and Matthews 1969) and similarities between this sequence and that of central-eastern Labrador (Short 1976) and northern New England (Bradstreet and Davis 1975).

\section{ACKNOWLEDGEMENTS}

Field work and laboratory analyses were supported by the University of Colorado Council for Research and Creative Work, by grants GB-25591 and GB-33497, U.S. National Science Foundation, Division of Biological and Medical Sciences. I thank Dr. J. D. Ives for discussion, and Drs. C. J. Heusser and P. J. Webber for comments on the manuscript. Mr. B. Gordon supplied valuable information and provided samples from the Hanbury-Thelon rivers site. Dr. R. C. Koeppen of the Forest Products Laboratory, Madison, Wisconsin, kindly identified wood samples. 


\section{REFERENCES}

ANDREWS, J. T. 1970. A geomorphological study of post-glacial uplift with particular reference to Arctic Canada. Institute of British Geographers, Special Publication no. 2, p. 157.

BARRY, R. G. 1967. Seasonal location of the Arctic Front over North America. Geographical Bulletin, 9: 79-95.

BARTLEY, D. D. and MATTHEWS, B, 1969. A palaeobotanical investigation of post-glacial deposits in the Sugluk area of northern Ungava, Quebec. Review of Palaeobotany and Palynology, 9: 45-61.

BRADSTREET, T. E. and DAVIS, R. B. 1975. Mid-postglacial environments in New England with emphasis on Maine. Arctic Anthropology, 12 (2): 7-22.

BRYSON, R. A. 1966. Air masses, streamlines, and the Boreal forest. Geographical Bulletin, 8 (3): 228-69.

IRVING, W. N. and LARSEN, J. A. 1965. Radiocarbon and soils evidence of former forest in the southern Canadian tundra. Science, 147: 46-48.

DUNbar, M. J. 1968. Ecological Development in Polar Regions. Englewood Cliffs, New Jersey: Prentice-Hall.

FRENZEL, B. 1975. The distribution pattern of Holocene climatic change in the northern hemisphere. In: Proceedings of WMO/IAMAP Symposium of Long-term Climatic Fluctuations, Norwich, England, August 18-23, 1975, Geneva: World Meteorological Organization (Publication no. 421).

hansel., R. I. C., Chant, D. A. and weintraub, J. 1971. Changes in the northern limit of spruce at Dubawnt Lake, NWT. Arctic, 24: 233-4.

HARE, F. K. 1950. Climate and zonal divisions of the Boreal forest formations in eastern Canada. Geographical Review, 40: 615-35.

HOLTMEIER, F. W. 1973. Geoecological aspects of timberline in northern and central Europe. Arctic and Alpine Research, 5 (3), pt. 2: 45-54.

Hustrch, I. 1966. On the forest-tundra and the northern tree-lines. Annales Univ. Turku., A, II, 36, Reports of the Kevo Subarctic Station, 3: 7-47.

IVES, J. D. 1976. Some comments on the stability of Alpine timberlines. In: Troll, C. (ed.), Geoecological Comparisons Between the Tropical High Mountains and the Southern Hemisphere. Wiesbaden: Franz Steiner (in press).

KöPPEN, W. 1936. Das geographische System der Klimate. In: Köppen, W. and Geiger, R. (eds.), Handbuch der Klimatologie, Vol. 1, Berlin: Gebrüder Borntraeger.

KREBS, J. S. and BARRY, R. G. 1970 . The Arctic Front and the tundra-taiga boundary in Eurasia. Geographical Review, 60 (4): 548-54.

LAMB, н. H. 1966. The Changing Climate. London: Methuen.

LARSEN, J. A. 1965. The vegetation of the Ennadai Lake area, N.W.T.: studies in subarctic and arctic bioclimatology. Ecological Monographs, 35 (1): 37-59.

1972. Growth of spruce at Dubawnt Lake, N.W.T. Arctic, 25: 59.

1974. The forest-tundra ecotone. In: Ives, J. D. and Barry, R. G. (eds.), Arctic and Alpine Environments, London: Methuen.

MARR, J. w. 1948. Ecology of the forest-tundra ecotone on the east coast of Hudson Bay. Ecological Monographs, 18: 117-44.

NICHOLs, н. 1967a. Pollen diagrams from sub-arctic central Canada. Science, 155: 1665-8.

1967b. The postglacial history of vegetation and climate at Ennadai Lake, Keewatin, and Lynn Lake, Manitoba. Eiszeitalter und Gegenwart, 18: 176-97. 
1970. Late Quaternary pollen diagrams from the Canadian Arctic Barren Grounds at Pelly Lake, northern Keewatin, N.W.T. Arctic and Alpine Research, 2 (1): $155-67$.

1972. A summary of the palynological evidence for late Quaternary vegetational and climatic change in the central and eastern Canadian Arctic. In: Vasari, Y., Hyvärinen, H. and Hicks, S. (eds.), Climatic Changes in Arctic Areas during the Last Ten Thousand Years. Oulu, Finland: Oulu University.

1974. Arctic North American paleoecology: the recent history of vegetation and climate deduced from pollen analysis. In: Ives, J. D. and Barry, R. G., Arctic and Alpine Environments, London: Methuen.

1975. Palynological and Paleoclimatic Study of the Forest-tundra Ecotone in Keewatin and Mackenzie, N.W.T., Canada. Boulder, Colorado: University of Colorado (INSTAAR Occasional Paper no. 15).

NORDENSK $\varnothing \mathrm{LD}, \mathrm{O}$. and MECKING, L. 1928. The Geography of the Polar Regions, New York: American Geographical Society (Special Publications, 8).

RITCHIE, J. C. and HARE, F. K. 1971. Late Quaternary vegetation and climate near the arctic tree line of northwestern North America. Quaternary Research, 1: 331-42.

ROWE, J. s. 1959. Forest regions of Canada. Canada Department of Northern Affairs, Forestry Branch, Bulletin.

1972. Forest regions of Canada. Canada, Department of the Environment, Canadian Forestry Service, Publication no. 1300.

SAvitle, D. B. O. 1972. Arctic adaptations in plants. Canada, Department of Agriculture, Monograph no. 6.

SHORT, s. K. 1976. Unpublished pollen diagrams, on file at INSTAAR, University of Colorado, Boulder.

Sorenson, C. J., knox, J. C., LARSen, J. A. and bryson, R. A. 1971. Paleosols and the forest border in Keewatin, N.W.T. Quaternary Research, 1 (4): 468-73.

WALCOTT, R. I. 1972. Late Quaternary vertical movements in eastern North America: quantitative evidence of glacio-isostatic rebound. Review of Geophysics and Space Physics. 10: 849-84.

WEBBER, P. W., RICHARDSON, J. W. and ANDREWS, J. T. 1970. Postglacial uplift and substrate age at Cape Henrietta Maria, southeastern Hudson Bay, Canada. Canadian Journal of Earth Sciences, 7 (2): 317-25. 